\title{
NIH urged to rewrite rules on consultancies
}

\section{Erika Check, Washington}

The National Institutes of Health (NIH) looks set to changes its employment rules to address criticism about conflicts of interest among its senior staff.

The changes were proposed on 6 May by an outside panel appointed by Elias Zerhouni, the NIH's director, after an article in the Los Angeles Times in December exposed shortcomings in the agency's existing conflict-of-interest policies.

The panel, which was chaired by Bruce Alberts, president of the National Academy of Sciences, and Norman Augustine, chairman of the defence contractor Lockheed Martin, said that the NIH should bar its most senior officials from earning money by consulting for industry or academic institutions.

"The NIH has honestly sought to apply the laws as it understands them, but there is room for substantial improvement in its conflict-of-interest policies," Augustine says.

Scientists who are allowed to do consultancy work should limit their compensation to $50 \%$ of their government salaries, the panel said, and spend no more than 400 hours a year on the work. Clinicians at the NIH would be subject to slightly less restrictive rules. But nobody at the NIH should be allowed to accept stocks or stock options as payment, it recommended.

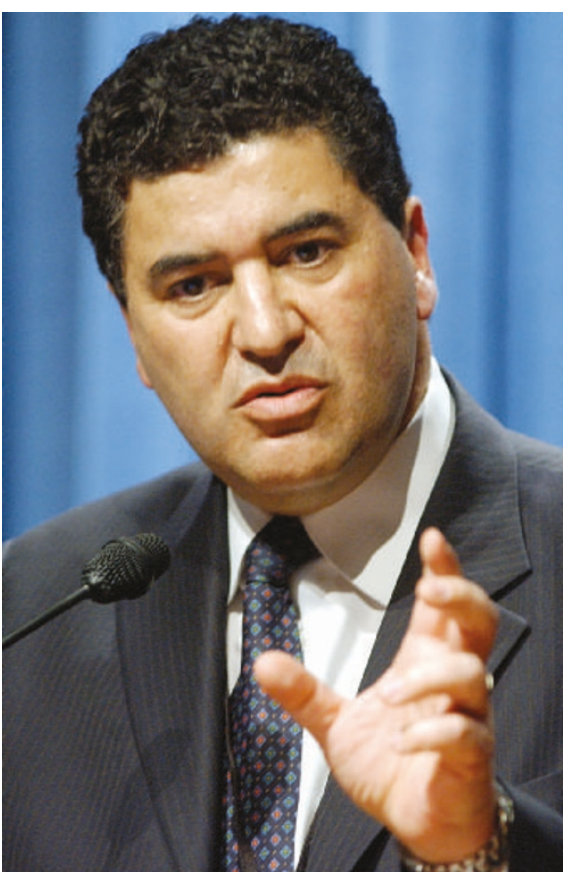

Elias Zerhouni: considering fundamental changes to prevent conflicts of interest.

To allay any negative impact on the agency's ability to recruit staff, the panel suggested that the health secretary raise the cap on the salaries that the NIH can pay them.

Zerhouni says that he will examine the recommendations and consult with his advisory committees before implementing any changes. "The recommendations are very clear, and they would profoundly change the way you would manage the agency," he says. But some of them, such as the salary changes, would require action from Congress.

Scientists' groups have supported the panel's findings. "I believe that what they came up with will provide more adequate protection without decreasing the attractiveness of the agency to scientists," says Jordan Cohen, president of the Association of American Medical Colleges.

"I think the report goes in the right direction," says Harold Varmus, former director of the NIH, who changed the agency's rules to let its scientists work with industry. But he adds that the strongest restrictions should apply to only a few scientists.

Varmus is critical of the the proposed bar on stock options, however. "I don't agree that having any stock - especially in a company that doesn't have publicly traded stock and may be worth nothing - is necessarily a conflict of commitment," he says.

But some patient advocates argue that the proposed rules don't go far enough. "They only partially address the underlying, corrosive conflicts of interest," says Vera Sharav, president of the New York-based Alliance for Human Research Protection.

\section{Vaccine targets gut reaction to calm livestock wind}

Carina Dennis, Sydney

The belches of millions of cows and sheep may not immediately seem like a serious problem. But for some countries they send greenhouse-gas emissions through the barnyard roof, thanks to methaneproducing bacteria in the animals' guts.

Scientists at Australia's largest research body, the Commonwealth Scientific and Industrial Research Organisation (CSIRO), now hope to change this with a vaccine that targets methane-producing bacteria. In a test on 30 sheep, the team's vaccine reduced methane emissions by $7.7 \%$ (A. D. G. Wright et al. Vaccine doi:10.1016/j.vaccine.2004.03.053; 2004).

Making methane is a ruminant's way of letting off steam. As food ferments in the animal's first stomach, or rumen, hydrogen is produced and reacts with carbon to form methane, which is then exhaled. Although this accounts for less than $3 \%$ of total greenhousegas emissions in fossil-fuel burning countries such as Britain and the United States, it makes up nearly $40 \%$ of emissions in agricultural New Zealand (see chart).

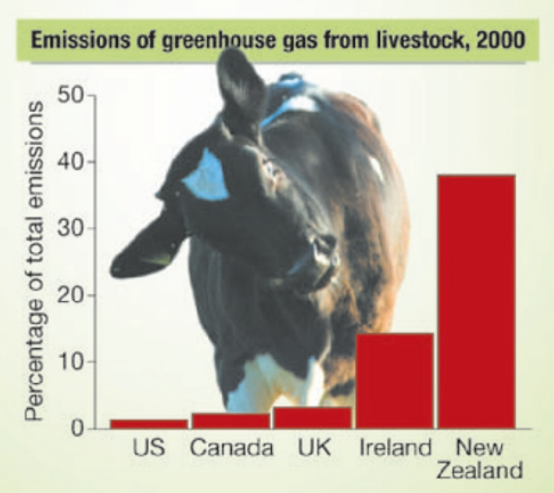

Andre-Denis Wright a molecular biologist at CSIRO Livestock Industries in Perth, who led the study, says that the team's vaccine should cut emissions by $20 \%$ once it matches the microbes in sheep better rumen bacteria vary from region to region and from season to season.

But critics point out that this diversity will also limit the vaccine's usefulness. "There are a huge number of microbes in the rumen that can't be cultivated. And if you can't cultivate them, you can't raise antibodies and can't make a vaccine against them," says Athol Klieve, a rumen microbiologist from the Queensland Department of Primary Industries and Fisheries in Brisbane.

Killing off some methane-producing bacteria in the gut may also open the way for other methane-producing microbes to take their place.

Wright's team hopes to get round these problems by tailoring the vaccine to target a protein common to many methaneproducing bacteria. Other groups are working on different solutions. Athol, for example, plans to introduce bacteria from the guts of kangaroos into cows in the hope that these will out-compete methaneproducing microbes. The kangaroo bacteria produce acetate instead.

But the vaccine will never eliminate methane production altogether, says Roger Hegarty, a livestock researcher for the New South Wales state government's agriculture department. Complete blockage of burping could result in an unhealthy build-up of hydrogen in the animals, he says. 